\title{
Legal Liability in Search and Rescue: A Canadian Perspective
}

\author{
Glenda Hanna \\ University of Alberta \\ Edmonton, Alberta
}

Things happen in the great outdoors. And sometimes, when things happen, people get lost or hurt. And when they get lost or hurt, they may rely upon any of a number of agencies or individuals who perform search and rescue (SAR) functions in society to find them and/or help secure first aid follow-up medical aid for them.

In general, whenever an agency or individual performs a SAR service, the people assisted and their families are very grateful for the aid rendered. However, where deficiencies in the quantity and quality of SAR service provided are perceived to have affected the victim's potential for survival or full recovery, potential for a liability claim exists. Recognizing the growth in such claims over recent years, it is incumbent on all SAR administrators and personnel to understand and appreciate legal liability and its implications, and to take steps necessary to manage physical and legal risks. While each case will be tried on its unique set of circumstances, there are a number of concepts and principles which can direct planning and operations and thereby reduce the likelihood of a liability suit arising and worse, succeeding against the agency.

In this article, the legal position and risk management program of Parks Canada will be used as abasis for discussion of this process. Parks Canada is an agency with significant SAR responsibility for individuals and groups pursuing outdoor recreation activities in and near National Parks. In addition to this discussion of professional SAR functions, the legally defined duties and responsibilities of volunteers engaging in SAR operations will be noted. It is easy to see how individuals involved in an outdoor education/recreation program could find themselves engaged in a search and rescue situation involving oneor more of their own participants or others encountered in the backcountry (Hanna, 1991). Many of the principles discussed herein will apply to those rendering emergency or first aid assistance in other sport and physical activity environments.

\section{DTATUTE LAW: THE CROWN LIABILITY ACT}

Historically, at common law, the King could do no wrong and therefore could not be sued,especially in his own courts. This privilege extended to his agents (the Crown). At least some states retain government immunity legislation which serves 
to protect the Crown and its employees, even when their errors or omissions cause loss to others. In Canada, statutes have been passed in all jurisdictions to enable individuals to sue the Crown as they could another individual or company. In Canada, the liability of the federal government is prescribed in the Crown Liability Act (R.S.C. 1970, c. C-38).

Section 3(1) of the Crown Liability Act reads:

The Crown is liable in tort for the damages for which, if it were a private person of full age and capacity, it would be liable:

(a) in respect of a tort committed by a Servant of the Crown, or

(b) in respect of any breach of duty attaching to the ownership, occupation, possession or control of property.

As an employer, the Crown assumes vicarious liability for the tortious errors or omissions of its servant staff occurring during the course of their employment. This principle of vicarious liability arises because of the existence of a master-servant relationship. With respect to a search and rescue situation in a National Park, Parks Canada is the employing agency. It hires, trains, and supervises its staff and so remains responsible for their actions. In addition, particularly with respect to a large agency like the federal government, the employer retains a much greater capacity to bear the financial cost of any demages awardedin such lawsuits. A servant is a person appointed or hired by the federal government for the performance of certain duties, in order to accomplish governmental purposes and who is under the control of government. While all Public Service employees meet the definition of servant, the roles of volunteers and commercial operators may not be as defined and should be clarified.

The Crown may also be held directly liable in respect to its ownership, possession or control of property. For example, Parks Canada has a prescribed duty to provide SAR services in National Parks. If the agency failed to provide what the courts deemed a sufficient number of trained personnel to meet this policy directive, the federal government could be held legally liable.

Interestingly, the Crown is also liable for damage incurred by any motor vehicle owned by theCrown. If the driver is found liable and the vehicle is owned by the Crown, then the Crown is liable, even if the driver is not an employee of the Crown. This could become relevant in a situation where a SAR vehicle is rushing to or from an accident scene (i.e., carrying a victim to hospital) and is involved in a motor vehicle accident not that unlikely a scenario.

It must be clear, however, that there is no liability for actions taken to carry out a statutory duty aslong as the individual is operating within the scope of his or her employment and due care and skill is exercised. For a civil suit in which an employee is found negligent, the Crown will pay the damagesassessed provided that the employee was acting within the scope of assigned duties (accepting reasonable deviation). Generally, a wrongful act will be deemed to be part of the employee's assigned duties if: 
(a) it was authorized by the employer, or

(b) it was a wrongful and unauthorized manner of doing some act authorized by the employer.

In the latter case, an example might involve a situation where a park warden employed an innovative albeit unrecognized lowering technique during a cliff exercise. It is the responsibility of SAR managers to ensure that their employees have good job descriptions which cover their assigned duties, and that employees have the skills and training necessary to complete their tasks.

The Crown and many other employers will not protect their employees when the incident was nota result of simple negligence, but of gross negligence, which suggests reckless or wanton disregard of others (for example, being impaired while engaged in a rescue effort). Where an employee is legally liable to reimburse the Crown because of an incident caused by gross negligence or conduct that is beyond the scope of employment, the employee may be required to pay back all or part of the full amount (as determined by the employer).

\section{Operational and Policy Decisions}

It is important for all SAR agencies, including Parks Canada, to recognize that they can be found liable for their operational decisions, but not for their policy decisions. If there is a discretion to do something (a power), the Crown must first give proper consideration as to whether it will exercise that power. Having done so, there will be no negligence in decisions involving policy or the allocation of resources. However, once these decisions are made, the Crown can be negligent in the operational implementation of these decisions.

For example, in a recent B.C. case (Just $v$. Her Majesty the Queen in right of the Province of British Columbia (1989), a man's daughter was killed and he was seriously injured when a rock worked loose froma steep slope above a highway and crashed down on his car. He sued, contending that the British Columbia government negligently failed to properly maintain the highway. The province countered that the number and quality of inspections as well as the frequency of scaling and other remedial measures were matters of planning and policy involving the utilization of scarce resources and the balancing of needs and priorities through the province. The appeals court upheld the trial court's finding that the entire system of highway inspection and the manner in which it was implemented involved a policy matter which did not give rise to liability. No finding was made as to whether the system of inspection was reasonable or whether the inspections themselves were properly carried out. It was held that it was in the discretion of the Department of Highways whether and to what extent it exercised its maintenance power.

Since the Crown can be negligent in the operational implementation of policy decisions, employees should be careful to follow policy (i.e., management directives). If management directives are not being followed for good reason, then the directives should be reviewed to ensure that they are still appropriate. Written rationale for the selected practices should be filed. 


\section{NEGLIGENCE}

The Crown, or any other SAR agency or individuals may be tried for negligence in a personal injury case. As noted previously, negligence is the failure to exercise that care which the circumstances demand. It may consist of not doing something which should have been done, or doing something which should not have been done or should have been done differently. To succeed in a negligence suit, the injured plaintiff must prove that the following five criteria for negligence are met:

1. A duty to rescue exists

2. Standard(s) of care are breached.

3. Actual injury(ies) are suffered

4. Negligence is the proximate cause of the injury(ies)

5. The plaintiff's position is not prejudiced (i.e., assumption of risk, contributory negligence).

A brief examination of each of these areas as they apply to professional and volunteer SAR personnel follows.

\section{Duty to Rescue}

The defendant must owe the plaintiff a duty of care. The determination of a duty of care in SAR situations is not always easy. In most parts of Canada, the individual is under no legal obligation to come to the rescue of a stranger to whom no initial identified duty was owed and who was not through his or her conduct placed in harm's way. The most common examples of pure legally acceptable nonfeasance may be found in motor vehicle accidents where many people, including doctors and registered nurses have been known to pass an accident scene without offering aid. Also, more than once a skilled swimmer has ignored a plea for help from a drowning person, again without legal repercussion. It appears that although statutory and common law are prepared to support altruistic action, they have stopped short of compelling it.

In Quebec, however, the law is defined by a strict rule. The Quebec Charter of Rights andFreedoms imposes a duty of affirmative action upon every person to provide assistance to anyone whose life is in peril, either personally or by calling for aid, ... unless it involves danger to himself or a third person, or he has another valid reason (R.S.Q. 1977, c. C-12, s. 2). A duty to rescue is also formalized in law in three U.S. states and most countries in Europe.

The duty of affirmative action (the legal duty to take positive action) exists only under certain circumstances in the rest of Canada. In general, it only exists where there is a special relationship between the two parties; parent/child (Arno v. Teno (1978), teacher/student McKay v. Board of Governors of School Unit No. 29(1968), physician/patient (Chattertonv. Gerson (1981), carrier/passenger (Dunn v. Dominion Atlantic Rv.Co. (1920), etc. For example, the Canada Shipping Act (R.S.C. 1985 , c. S-9, s. 451) states that the master of a ship has a legal as well as a moral duty to rescue anyone found at sea and in danger of being lost.

Recent cases suggest the existence of prospective economic gain may also underlie a duty to rescue. In a case with particular relevance to National Parks (Crockerv. Sundance Northwest Ski Resort Ltd. (1988), the defendant ski resort was 
held negligent for allowing ain inebriated patron to participate in a downhill tubing race during which he was seriously injured. Wilson J. reasoned that when a ski resort establishes a competition in a highly dangerous sport and runs the competition for profit, it owes a duty of care towards visibly intoxicated participants (p. 1198). Not only does the Supreme Court finding clarify the standard of care expected of ski resort concessionnaires, but it also has implications for Parks considering initiating user pay systems for backcountry trail or river travel.

While perhaps more nebulous in distinction, the duty to rescue also exists:

i) Where the defendant innocently or negligently created the perilous situation in which the plaintiff found him or herself (Spratt $v$.

Edmonton (1941));

ii) If the defendant's innocent or negligent act worsened the plaintiff's situation (Horsely v. McLaren (1971));

iii) If the defendant's innocent or negligent act denied the plaintiff otheropportunities for aid (H.R. Moch Co. v. Rensselaer Water Co. (1958)), or

iv) If the defendant induced the plaintiff to rely on the defendant to the plaintiff's detriment (i.e. induced him or her into a false sense of security).

The Crown can be obliged by statute to perform SAR functions. Staff of Emergency Medical Aid agencies like RCMP, fire and ambulance services also have a duty of affirmative action. Where a lifeguard is employed at a swimming area, there is an implied duty to go to the rescue of swimmers in distress. Interestingly, Parks Canada does not have a statutory obligation to perform SAR work in its parks and historical sites. However, the agency itself maintains that visitor safety is a responsibility of the warden service which could be interpreted by the courts to include some SAR capability. This has yet to be tested in the courts, but will likely be over the next year as current cases are brought to closure.

\section{THE DUTY TO RESCUE RESCUERS}

Canadian courts have long recognized the altruistic values associated with rescue efforts (Seymourv. Winnipeg Electric Ry. Co. (1910)). In a 1935 case (Haynes v. Harwood), Greer, LJ. stated that, It would be a little surprising if a rational system of law...denied any remedy to a brave man who had received his injuries through [rescue] (p. 152). We all recognize that if we create a situation through our negligence which results in harm to another, we may be held liable for any losses incurred by that person. However, we can also be found responsible for damages sustained by a third party who attempts to rescue the first victim. The courts assume that we should know that some brave person is likely to risk their own life to save someone in need and we owe a duty of care to the rescuer as well as the original victim of our wrongdoing (Chadwick v. British Transport Comm. (1967))

In the leading rescue case of Mathews and Horsely v. MacLaren (1969) referred to as theOgopogo, The Ogopogo was a cabin cruiser owned by MacLaren. Through no fault of MacLaren, one ofhis guests (Mathews) fell overboard. Despite 
an immediate rescue attempt, Mathews was unconscious and could not be helped back aboard. Unexpectedly, Horsely, a second guest, dove in to rescue Mathews. It appears he also succumbed to the icy water of Lake Ontario, and although he was rescued quickly, he never revived. Mathews' body was never found.

Mathews' and Horsely's families sued MacLaren, claiming negligence. The courts found that an occupier has a positive duty to aid and rescue a lawful guest, and that there is a duty to take all reasonable care once a rescue is undertaken. Further, the person who negligently created the dangerous situation is responsible to rescuers as well as to the original victim. In the case of the Ogopogo, MacLaren was not found negligent in Mathews fall overboard and so was not held liable for either his or Horsely's deaths.

This case demonstrates that there is a common law duty of affirmative action owed lawful passengers by their carriers or visitors by the occupiers of a given premises. Second, anyone who creates a dangerous situation will be liable not only to the victim but also to the rescuer, as long as the rescuer was not so utterly foolhardy so as to be responsible for his or her own injury.

In the case of Moddejonge v. Huron County Board of Education (1972), an outdoor education program coordinator was held not only liable for the death of a nonswimming student who waded into deep water and drowned due to his negligence, but also for a second girl who could swim, but who drowned when she attempted to rescue the panicking nonswimmer. In explaining his finding in this case, the judge claimed that:

The initial act that set the events in motion was the negligence of the defendant. One of the links of causation was that someone might thereby be exposed to danger and that someone else might react to the impulse to rescue.

Interestingly, the duty owed to a potential rescuer is independent of that owed the initial victim. Therefore a person may be found liable for injuries sustained by a would-be rescuer, but not for the injuries sustained by the initial victim the rescuer was endeavoring to aid (Videan v. British Transport Comm. (1963)).

A number of American states have passed so-called Firefighter's Rules, named when a firefighter successfully sued a tort feasor who was responsible for negligently setting a fire which resulted in serious injuries to the firefighter. These rules apply to fires from unusual or exceptional risks (such as arson) rather than accidental fires which the firefighter expects to fight. While no complementary statutory law has been enacted in Canada, the Commonwealth has long recognized this principle in its jurispudence (Baker v.Hopkins (1959); Ogwo v. Taylor (1987)).

\section{Standard of Care}

The standard of care expected in a SAR situation will depend upon the relationships between the rescuer and the victim and the professional status of the rescuer. Over 30 states in the U.S. and a number of provinces in Canada (e.g., Alberta, Saskatchewan, Manitoba) have enacted legislation (so-called Good Samaritan laws) to protect any person rendering emergency first aid assistance from civil liability actions, unless they are found grossly negligent. Alberta's Emergency Medical Aid Act, the first of its kind in Canada, states that: 
If, in respect of a person who is ill, injured or unconscious as the result of an accident or other emergency,

a) a physician, professional medical assistant, or registered nurse voluntarily and without expectation of compensation or reward renders emergency medical services or first aid assistance and the services or assistance are not rendered at a hospital or other place having adequate medical facilities equipment, or

b) a person other than a person mentioned in clause (a) voluntarily renders emergency first aid assistance and that assistance is rendered at the immediate scene of the accident or emergency,

the physician, professional medical assistant, registered nurse or other person is not liable for damages for injuries to or the death of that person alleged to have been caused by an act or omission on his part in rendering the medical services or first aid assistance, unless it is established that the injuries or death were caused by gross negligence on his part (R.S.A. 1975 (s), c. 26, s. 82(2b)).

Although most provinces (eg., Manitoba, Quebec, Ontario and New Brunswick) do not possess such statutes, common law may be relied upon to give guidance in these provinces. Case law has demonstrated that although a duty will be imposed upon a would-be rescuer to complete a rescue initiated (H.R. Moch Co. v. Rensselaer Water Co. (1958)) the standard of care required in such situations appears quite low. As long as the rescuer's conduct doesn't worsen the condition of the victim's position noticeably, thereby constituting misfeasance, the rescuer is under no legal obligation to significantly improve the status of the imperiled victim. To hold otherwise would have the undesirable effect of discouraging assistance for fear of incurring liability if the most expeditious methods were not employed.

In Horsely et al. v. MacLaren et al. (1969), the plaintiffs based part of their case on the fact that the defendant MacLaren had used an unorthodox method to approach Mathews, backing the boat up to himrather than approaching bow on as was customary. The court felt that, while perhaps demonstrating poor judgment, MacLaren's actions during the rescue attempts could not be viewed as legally misfeasant.

The standard adopted was set for the Commonwealth in an earlier British case where the justice noted:

...where a person gratuitously and without any duty to do so undertakes to confer a benefitupon or go to the aid of another, he incurs no liability unless what he does worsens the condition of that other.(East Suffolk Rivers Catchment Board v. Kent et al. [1941] A.C. 74)

Several states (e.g., Maryland, Mississippi, Arkansas) require the standard of care of the reasonable person be met (reasonable, prudent care). However, none seem to specifically address the issue of the individual acting in an amergency, with time pressure, emotional trauma and other stresses. This seems incongruent with the intent of Good Samaritan statutes to provide immunity for ordinary negligence of those offering emergency aid with no expectation of recompense.

In Canada, this principle of limited liability extends to situations where an individual initiates careof an injured person, and then, for whatever reason, ceases 
these efforts. In the Horsely case, the judge noted that:

... if a person embarks upon a rescue, and does not carry it through, he is not under anyliability to the person to whose aid he has come as long as discontinuance of his efforts did not leave the other in a worse condition than when he took charge (Ibid., at p. 500).

It would be unfair to hold someone liable for failing to effect a rescue attempt with due care whenthere is not legal obligation to do anything, unless the rescue effort prevented other help from being offered or otherwise worsened the condition of the victim. The well-intentioned will only be liable where his or her actions do not meet the standards required and the victim is put in greater danger by being left in a situation where other help cannot be obtained, where the individual cannot help themselves, or where their situationis otherwise worsened.

The purpose of the law cited in these cases, supporting statute in a few provinces, is to encourage rescue efforts by reducing the risk of liability for failing at such. It is generally difficult to prove that a rescuer's efforts actually worsened the condition of the victim. It typically is not easy to prove that others would have rendered aid sooner or more effectively. The statutory exclusion of protection for grossly negligent rescuers helps deter the completely inept from engaging in careless or foolhardy rescue operations (Seymour v. Winnipeg Electric Ry. Co. (1910); Carrothers v. Slobodian (1974)). Where a rescuer's losses are found partially attributable to contributory negligence, damages will be apportioned according to perceived responsibility.

\section{SAR Professional Standard of Care}

SAR delibery agencies may be found liable for failing to meet standards of care expected under personal or vicarious liability. The standard of care expected of a person operating as a SAR professional is that degree of care which would be shown by the reasonably prudent professional operating in like circumstances. For example, in a case pending against Parks Canada (Albrecht et. al. v. Parks Canada), a ten-year-old boy died of hypothermia after falling into a crevasse while walking with his family on the famous Columbia Icefields. The Public Inquiry held into the death (independent of the civil suit brought) made recommendations to Parks Canada regarding:

1. Improved warning signage and written information.

2. Review of staff numbers at the closest warden station.

3. Installation of a means of placing emergency calls from the parking lot at the glacier.

4. Assess ambulance facilities in the area with respect to vehicle and radio maintenance.

As Public Inquiries have no binding power and do not necessarily imply errors consistent with negligence, these recommendations must be considered as that, recommendations for future practice. However, they do highlight areas that the agency, in this case Parks Canada, could be held personally as opposed to vicariously liable. 
Society can reasonably expect more from a specialist than a generalist. For example, the standard of care demonstrated by a park warden who is employed as a SAR specialist can and should be higher than a general warden who spends only a small portion of his or her time training for and engaged in SAR operations. But, inexperience is not an answer to a claim of professional negligence. A newly hired warden or other SAR professional will be held to the standard of the reasonable professional in a similar position, regardless of the number of years of experience the employee has.

While individuals working as SAR professionals will be expected to conform to the standard of the ordinary practitioner, evidence of general practice is not necessarily conclusive evidence of reasonable care. It becomes difficult to predict the outcome of a case where different practitioners use and/or advocate different methods. It also must be recognized that SAR involves a technology that is continually evolving and that is affected by the availability of human, equipment and financial resources, terrain, weather and a host of other factors. Generally, a SAR worker will be tried at the standard of one in like circumstances so geography, and policy decisions affecting activity of facilities, equipment and specialists may increase or decrease liability. For example, in some of Canadian newer, more remote and less visited national parks (e.g., Kluane, Kejimijik) one won't see fewer SAR specialists than in Banff and Jasper where sheer numbers of visitors and the variety of outdoor activities pursued increase the need for SAR support.

Courts cannot and will not argue in technical matters where there is unanimous consent among practitioners of practices followed. Judges cannot come to conclusions on technical matters (other than domestic or constitutional law) founded on their own opinions rather than on evidence from qualified witnesses.

In sum, SAR employees should keep abreast with developments in their field, maintain their skills, and undertake all assistance using as much care as they can in the situation. The presentations and discussions the NSS is entertaining regarding the establishment of national standards for SAR in Canada are worth pursuing as a means of promoting coordination and simplification of the system. The U.S. has already developed national SAR standards. Written standards can, however, lead to a higher overall level of expectations that the standards will be adhered to and may increase potential liability when they are not.

\section{Actual Injury Suffered}

The plaintiff must demonstrate that he or she has suffered actual harm or loss. This harm may involved physical and/or psychological injury, but it must be established by medical and/or psychological examination. Individuals cannot sue because they could potentially have been injured by a situation, or because they are annoyed or angry at SAR personnel because they were too slow or for whatever reason. Typically, demonstrating real injury(ies) is not a problem, but sometimes quantifying it into assessable damages can be more difficult. This is consistent with all such claims in the Commonwealth and the U.S. 


\section{Proximate Causation}

The injured plaintiff must be able to demonstrate a clear connection between the perceived negligent conduct of the SAR defendant and the injury(ies) the plaintiff sustained. The courts use a sine qua non (but for) test: would the accident have occurred without the negligent conduct of the defendant? They look to see if the outcome was a foreseeable eventuality of that conduct. The existence of this criteria is the major reason there are so few lawsuits for negligence filed against SAR agencies and personnel. In most instances, SAR personnel are called to assist an individual/group who has/have been lost or injured already. Because the condition existed before the SAR people arrived on the scene, the SAR agency and personnel cannot be held liable for the initial loss/injury. They may, however, be held accountable if their actions or omissions aggravated or worsened the victim's condition.

As noted previously, it may be acceptable for the lay person to initiate and then cease a rescue effort (as long as this action did not preclude other assistance). However, professional SAR agencies and personnel are bound legally and ethically to continue searching for or treating a lost or injured victim until responsibility for patient care is transferred to another medical professional of an equal or higher level or skill, or until the victim is transferred to a medical facility. The only exceptions may arise when the rescuers' own lives are in jeopardy, as for example in extremely bad weather (e.g., white out blizzard) or exhausting conditions where reinforcements aren't available for a time (e.g., an arduous cave rescue).

As discussed above, an injured victim will not be successful in a negligence suit against an untrained volunteer rescuer unless it can be proven that he or she was left worse off than they would have been without the aid rendered. This is very difficult to prove.

However, there is some indication that a higher standard of care may be expected of professional SAR personnel. For example, in Bayus vs. City of Coquitlam the owners of a duplex house called 911 to report that their home was on fire. There were a number of areas of confusion on both sides, and as a result the fire department was delayed by some four minutes. This delay came at a critical time when the fire was spreading rapidly, and it was determined that had water been put on the fire four minutes earlier, there would have been less damage to the duplex. The city was found negligent in its failure to maintain accurate maps of the area, and to ensure that technical standards of fire fighting were maintained and was held responsible for fifteen percent of the damages resulting from the delay.

\section{Plaintiff's Position Not Prejudiced}

An individual who is participating in a high risk outdoor pursuit (e.g., rock climbing, whitewater canoeing, ski mountaineering, etc.) assumes the risks inherent to participation in the activity (eg., falling, drowning, burial in an avalanche). In addition to assuming inherent risks, participants in such activities sometimes sign assumption of risk and waiver forms provided by commercial operators which extend therisks accepted by the individual. For these reasons, it is highly unusual for people engaged in wilderness recreation to sue SAR agencies and personnel when they endeavour to render aid. 
In addition, individuals must demonstrate that they did not, by their own actions, cause the injury(ies) they sustained. In Canada, as in the U.S., this must not fail to meet the standard of care expected with regard to taking care of themselves. As SAR personnel tend to be drawn into rescue situations where the victim is already lost and/or injured, it is not uncommon for one or more of the errors or omissions committed by the victim to have contributed to the harm sustained. In Canadian courts, where a defendant successfully counters a claim of negligence with one of contributory negligence on the part of the victim, the judge may choose to apportion the plaintiff's damages. He or she will determine a ratio in accordance with the relative responsibility it is felt each party contributed to the damages.

Finally, a rescuer owes a duty to another potential rescuer to exercise reasonable care during the course of the initial rescue. However, few recent cases exist where an injured would-be rescuer has been denied recovery based on voluntary assumption of risk, the defendant's lack of duty and/or the rescuer's own contributory negligence.

\section{RELATIONSHIPS WITH OTHERS}

\section{Volunteers}

An agency like Parks Canada may use volunteers in various SAR operations. The agency recognizes the use of volunteers increases its exposure to liability and endeavours to manage this risk. While volunteers may be protected under statutory or common law (as discussed above), they are still wherever possible indemnified against third party liability claims. Parks Canada, as an agent of the Crown, seeks to provide group insurance to volunteers who have signed a valid promissory agreement. Some volunteer SAR associations/groups are incorporated under their province's Societies Act and therefore are indemnified on that basis. However, most are not so the protection government offers is appreciated.

Parks Canada also tries to provide volunteers with accidental death and dismemberment insurance protection similar to that of employees working in comparable risk situations. However, volunteers are required to provide their own collision and third party liability coverage when using their own vehicles. This area is a source of great concern to many volunteer SAR providers, recognizing that not only their cars may be drawn into action, but their boats, all terrain vehicles, snowmobiles, etc.) None of these vehicles is specifically protected.

The legal status of SAR volunteers has not been clarified in the courts. But, volunteers who are pressed into service would probably meet the definition of Crown servants under the Crown Liability Act. The Crown would be held vicariously responsible for their actions. Recognizing this, Parks Canada and other Crown agencies charged with SAR responsibilities must endeavour to properly recruit, train, supervise and support their volunteer personnel. The employees appreciate that they owe a duty of care to volunteers to provide them with as safe a system of working as circumstances permit. This may include providing adequate instructions and guidance to volunteers, warning them of known dangers and hazards, and other general and specific actions. 


\section{Commercial Operators and Contractors}

There are many third parties operating in parks and sites, including commercial operators (e.g., lessees, licensees, concessionaires and guides) and contractors. Generally, once risks have been identified, these operators and contractors are asked to sign exculpatory agreements to indemnify the Crown, ... from and against all claims, demands, losses, costs and expenses, in any manner based upon, arising out of or connected with... the use or occupancy of the premises . This includes indemnification against all costs arising from liability suits, including those associated with SAR.

While the Crown is self-insured, it requires commercial operators to obtain and maintain general liability insurance. Minimum insurance requirements are clearly specified in each terms of reference or memorandum of understanding.

Parks Canada's Business Regulations require that guides hold both a business licence and a valid guide certificate for the activity (e.g., Association of Canadian Mountain Guides) and area in question. In order to qualify for the guide certificate, the applicant must have appropriate knowledge of park regulations, first aid certification and the prescribed qualifications for guides as set out in the regulations. Where external certifications do not exist (as, for example, with whitewater rafting), the Park Superintendent must determine the qualification of prospective guides. Here, appropriate written standards may be useful in defending the agency against litigation.

With respect to the hiring of contract employees, Parks Canada endeavours to establish a contractual relationship and to avoid entering into an employeremployee relationship. This places responsibility for the actions of the contractor with the contractor and not vicariously with the agency. The keys to differentiating these relationships lie in the following:

Essentially, an employer-employee relationship exists when an employer can specify when, where, how and under what conditions the work will be performed.... A contract for service exists when an individual is retained to achieve a prescribed objective with no day-to-day supervision by the contracting authority. (Government Contract Regulations, s. .16.3.1, .16.3.2)It is essential that all parties entering into contractual relationships understand and appreciate their legal responsibilities.

\section{Other SAR Agencies}

Parks Canada's mandate ends at the boundaries of our national parks and historical sites. The agency doesn't endeavour to develop SAR expertise to respond to accidents outside these areas unless these incidents are expected to occur immediately adjacent to the park and are directly associated with visitor facilities or visitor programs provided in the park.

The RCMP generally pick up ground search responsibilities outside park boundaries. TheDepartment of National Defence is responsible for searches for missing aircraft in national parks. The Coast Guard is responsible for marine SAR in Canada marine parks. Parks Canada reports incidents to the Rescue Coordination Centre and assists as requested to do so by this lead agency.

Parks Canada uses medical evacuation services provided by other agencies to evacuate accident victims to medical treatment facilities. Exceptions may occur in 
some remote parks where wardens may be equippedto evacuate accident victims directly to the nearest ambulance carrier or medical treatment facility (eg., Banff). Where specialized expertise is required to provide some element of a park's SAR service and this expertise already exists locally in another national park, government agency or volunteer group, first consideration is given to using this existing expertise to provide the service necessary.

Whenever Parks Canada provides service to other agencies, like DND, the Coast Guard or RCMP or uses other agencies or groups to augment its own SAR service, these relationships must be clarified in a memorandum of understanding between the parties involved. Factors such as mutual roles and responsibilities, decision making authorities, call our procedures, and cost reimbursement policies and procedures must be clear. Such letters of understanding directly and indirectly help establish legal responsibilities for cooperative SAR operations.

\section{WHEN ACCIDENTS HAPPEN}

Things happen in the great outdoors. And sometimes, when things happen, people get lost or hurt and require assistance. However, the manner in which a SAR operation is conducted can lead to decreased or increased potential for liability and it is important to know how. These points are not significantly different from what any physical activity leader should consider in the event of an accident. The following protocol steps may reduce the potential for subsequent lawsuits.

1. Use a systematic approach to ensure that the SAR team will not be jeopardized before initiating and throughout rescue efforts. As soon as possible, begin treating the victim(s) and evacuating to follow-up medical aid. Demonstrate a caring, considerate attitude at all times. Many actionable cases are never tried because people believed SAR people cared and were trying their best.

2. Do not make any admissions of fault or liability. While generally only a problem for the Crown with respect to leading a plaintiff to consider suing for damages, with some agencies who are not self-insured, such admissions of responsibility may in fact void the agency's insurance contract.

3. Complete and file a written accident report as soon as possible. Focus on the facts (date, time, area description, incident description, victim description and condition, weather conditions, emergency procedures, equipment used, victim's and/or witnesses statements, laws or regulations violated, and other documentation as appropriate. Document the situation as much as possible using video, photographs, diagrams or sketches. Remember that it can take several years for a case to end up in court and memories will fade with time.

4. Avoid discussions with the media. An agency spokesperson will be assigned this task as appropriate. In a recent Parks Canada case, the agency was successfully sued in part because a warden errantly commented to the media that it was safe to go back into an area where a bear mauling had occurred. While a suspected bear had been shot, the bear 
actually responsible for the mauling was still at large in the area and when he mauled another tourist the victim sued, saying Parks Canada had lulled him into a false sense of security (Tobler. v. R. in the Right of Canada (1993)).

5. Seek legal assistance if there is any concern that the incident may give rise to a claim for damages. While most potential claims are never pursued, and others end up settled out-of-court, it is important to be prepared for the few that may end up there.

The treatment of any case will involve one of a number of alternatives. The defendant SAR agencymay admit liability and settle the claim, they may settle the claim out-of-court without admitting liability, or they may deny liability and fight it out in court. The outcome in this last situation will be that the judge will decide whether the defendant is liable, whether the plaintiff or another party shares some of the responsibility, how much damages will be paid, and in what proportion by each party.

\section{CONCLUSIONS AND RECOMMENDATIONS}

In summary, it is important for search and rescue administrators and personnel to understand their policy directives and to establish their operations procedures in accordance with these. A systematic approach to risk management is crucial, before, during and following a SAR operation. Generally, SAR personnel will be vicariously protected from liability by their employer, but this may not be the case if they are contracted employees. Individuals should be clear about their employment status and the legal implications of this status.

In Canada, while the general public will not have a duty to rescue individuals they find in trouble (except in Quebec), SAR agencies will have a duty of affirmative action. The standard of care expected will be higher for SAR specialists than for the general public, but the bottom line will be whether the victim's situation was worsened by the actions of the rescuer. SAR agencies are encouraged individually and collectively to establish and maintain clear standards for practitioners. This is the best way of increasing the success rate of SAR operations and concomitantly reducing the potential for litigation to succeed. To date, fortunately, there are few cases in Canada or the United States clarifying the law regarding SAR situations. However, pending cases may change this. 


\section{References}

\section{Cases}

Baker v. Hopkins [1959] 3 All E.R. 225.

Chadwick v. British Transport Comm. [1967] 2 All E.R. 945 (Q.B.)

Chatterton v. Gerson [1981] Q.B. 293.

Cleary v. Hansen (1981) 18 C.C.L.T. 147 (Ont. H.C.)

Crocker v. Sundance Northwest Ski Resort Ltd. [1988] S.C.R. 1186.

Dunn v. Dominion Attlantic Ry. Co. (1920) 60 S.C.R. 310.

East Suffolk Rivers Catchment Board v. Kent at al. [1941] A.C. 74.

Harrision v. British Railways Bd. [1981] 3 All E.R. 679.

Haynes v. Harwood [1935] 1 K.B. 147.

Horsely v. McLaren (1971) 22 D.L.R. (3d) 545.

H.R. Moch Co. v. Rensselaer Water Co. [1958] 159 N.E. 896.

Just v. Her Majesty the Queen in right of the Province of British Columbia [1989] 2 S.C.R. 1228.

Mathews and Horsely v. McLaren et.al. (1969), 2 O.R. 144.

Moddejonge v. Huron County Board of Education (1972), 2 O.R. 437 (Ont H. Ct.).

Ogwo v. Taylor [1987] All E.R. 961 (H.L.)

Seymourv. Winnipeg Electric Ry. Co. (1910) 19 man. R. 412.

Spratt v. Edmonton [1941] 2 W.W.R. 456 (Alta. C.A.).

Toblerv. R. in Right of Canada (Minister of the Environment) [1991]3 W.W.R.638.

Videan v. British Transport Comm [1963] 2 Q.B. 650 (C.A.)

\section{Statutes}

Crown Liabiltiy Act, R.S.C. 1970, c. C-38.

Quebec Chater of Rights and Freedoms, R.S.Q. 1977, C. C-12, s. 2.

Canada Shipping Act, R.S.C. 1985 c. S-9, s. 451.

Emergency Medical Aid Act, R.S.A. 1975 (2), c. 26 (Alberta). 
Emergency Medical Aid Act, R.S.N.W.T. 1988, c. E-4 (Northwest Territories).

Emergency Medical Aid Act, S.N. 1971, No. 15 (Newfoundland).

Emergency Medical Aid Act, R.S.S. 1978, c. E-8 (Saskatchewan).

Emergency Medical Aid Act, R.S.Y. 1986, c. 52 (Yukon).

Good Samaritan Act, R.S.B.C. 1979, C. 155 (British Columbia).

Medical Act, R.S.P.E.I., 1988, c. M-5, s.50 (Prince Edward Island).

Volunteer Services Act, R.S.N.S. 1989, c. 497 (Nova Scotia).

\section{Books and Reports}

Public Inquiry into the death of Timothy Albrecht.

American Academy of Orthopaedic Surgeons (1987). Emergency Care and Transportation of the Sick and Injured. Fourth Edition. Park Ridge, Ill.

Canadian Parks Service (1993). Visitor Risk Management Framework Draft. Ottawa: CPS.

Canadian Parks Service (1993). Visitor Risk Management: Proposed Risk Assessing and Risk Control Guidelines. Ottawa: CPS.

Canadian Parks Service (n.d.). Tort Liability Handbook. n.p.

Environment Canada Parks (1986). Management Directive: Public Safety Management 4.4.4.

Hanna, G. (1991). Outdoor Pursuits Programming: Legal Liability and Risk Management. Edmonton: University of Alberta Press.

McInnes, M. (1993). The Law and Theory of Emergency Intervention. Unpublsihed manuscript. Ottawa, Ont. 